\title{
The Shirts That Mande Hunters Wear
}

\section{PATRICK R. MCNAUGHTON}

"A tree trunk can stay forever in the water and never become a crocodile."

Jirikuru men o men ji la, a te ke bama ye.

Tn t n the Mande world, hunters are considered by the rest of their society to be extraordinary individuals (Fig.1). ${ }^{1}$ If we divide the enterprise of civilization into theory-what a society's ideology says people should be-and practice-what those people actually are-then theoretically Mande hunters hold unique positions within their West African culture area. They are very much a group set apart, and this separation is everybody's doing. Hunters choose to isolate and distinguish themselves in several ways, and for several reasons, while the rest of society, for its own reasons, is very much interested in holding the hunters at bay, at least most of the time.

First of all, hunters have an incredible thirst for adventure, along with the pluck and determination to indulge that thirst and survive. They are also by and large very self-possessed and very self-oriented, features that are both good and threatening to the rest of society. Hunters develop, if they are good, a corpus of impressive physical skills, which make them quite different from most other people. They develop as well a refined set of supernatural skills that make them very potent and potentially dangerous. Finally, most hunters aspire to be heroes, that is, to become so renowned within the Mande world that their names are forever remembered in Mande oral history. Often they don't mind disrupting the rest of society to become famous, and that fact linked with these other characteristics make hunters a group to be reckoned with. In fact they are organized into groups, fraternities called donson ton that offer the camaraderie of like minds and unite individual practitioners from a number of communities in a formal structure of support and respect. Hunters' organization branches hold meetings, gather for the funerals of their members and sometimes stage group hunts. They are viewed as a formidable association with considerable power. Such groups, we think, formed the corps of crack troops in the armies that helped build Mande states and empires. In theory their capacities and appetites make them an aggressive and fearsome lot, against which the rest of society must remain on guard. At the same time, hunters are important resources when society is subjected to internal or external stress and iron-willed individuals are needed to pull it back on its feet.

Thus hunters are an anomaly, and they generate high levels of ambivalence in Mande civilization. The clothes they wear, most notably their shirts and hats, encode in no uncertain terms the anomaly that hunters represent and the ambivalence that they generate. The shirts (donson dlokiw) in fact are symbols with a complex set of references, which ultimately include very nearly every aspect of the hunters' abilities and their roles in traditional society. They use them to proclaim themselves, this in a civilization where clothes reveal a great deal about their wearers. We can use these hunters' clothes as focal points for understanding hunters, and in the process we will begin to see the clothes as the Mande themselves see them.

\section{The Mande and Their Hunters}

Like the Bantu, the Mande have long been an expansive civilization. The great Mali Empire, for example, was founded in the 13th century A.D. by the Maninka (Malinke), a core ethnic group in Mande civilization. The Bamana (Bambara), another core group, established in the early 17 th century the large and powerful states of Kaarta and Segou. Just before colonialization the Dyula, another core group, created quite a large empire that was growing rapidly when the French finally subjugated it and began to establish an empire of their.own.

During the course of all this empire building the Mande systematically enlarged the territory they controlled. The Mali Empire sent colonists to settle the Gambia River basin, and thus a series of small kingdoms were established-initially owing allegiance to old Mali but gradually establishing their own autonomy. These states controlled much of the trade that came to the coast, and they remained politically and economically powerful until the middle 1800s (Quinn 1972:9-11). To the south and east the Mali Empire sent groups of traders and blacksmiths to tighten their grip on the gold trade and refine the technologies used to amass that precious material. Today large groups of Mande Dyula, Ligbi and Numu (blacksmiths) are prominent components of the ethnic complexion of western Ghana and the Bondoukou region of Ivory Coast (Bravmann 1974:59-73).

In a somewhat less systematic fashion, the Mande have been very influential south of their savanna homelands, in what are now modern Guinea, Ivory Coast, Sierra Leone, and Liberia. When the Mali Empire began to fall, for example, many Maninka infiltrated the lands to the south, displacing indigenous populations and establishing their own political order. They settled first in Guinea, but then, apparently under the leadership of a clan segment bearing the last name Mara, they spread into northern Sierra Leone (Jackson 1977:1-3). These people are now known as the Kuranko, and they represent but a single instance of the kind of aggressive enterprise for which the Mande have become very well known.

Embedded quite securely in Mande civilization is a pair of concepts that help very much to explain this tendency to expand and take over, and which also pertain directly to hunters and their clothes. These concepts are called Badenya, "mother-childness," and Fadenya, "father-childness," and they are derived from the nature of Mande polygamous households. Siblings born of the same father and mother-full siblings that is - are called Badenlu, "mother's children," and they may be characterized by the word "affection" because in 
theory such siblings are very close and very devoted to one another. Siblings born of the same father but different mothers are called Fadenlu, "father's children," and they may be characterized by the term "competition," because within the structure of the family, and beyond, they will compete with one another to make names for themselves within their clans' genealogies (Johnson 1978:94-97; Bird 1974:vii; Bird \& Kendall 1980:14-16).

By extension Badenya, "mother-childness," identifies a gentle and benign component of human character. It identifies the will to put oneself after others, to be devoted and, indeed, dominated by family, community, and society. People whose characters are dominantly Badenya can be quiet, sturdy citizens who strive not to make waves and not to stand out. They fit very neatly within the fabric of society and they will probably live quite comfortably in its fold.

Fadenya, "father-childness," by contrast identifies a very aggressive component of human character. It identifies the will to put oneself before the group, to act in defiance of it and to disrupt it if need be, in order to accomplish some personal goal. People whose characters are predominantly Fadenya do not fit well within the fabric of society. They live emotionally and very often physically out on the fringes of society, where they can feel free to move about without the encumbering structure of civilization constantly qualifying their actions. Most often their actions are dictated by the desire to achieve fame, to become renowned, ironically enough within the very society they shun.

From a very early age Mande young people are charged with Fadenya, or at least exposed to it. It comes at them in the praise songs and epic performances about the Mande's great heroes, like Sunjata Keita, the legendary Lion King who founded the Mali Empire, or Fakoli, his famous strategist and dangerous general, or Kambili, a recent hero from the time of the Dyula Empire, who is alleged to have saved a sizeable portion of it from treachery and malevolent sorcery.

These songs and epics are sung by bards (jeli), an endogamous group of professional musicians and oral historians who train for years to become refined and influential performers. The best are influential indeed. With their virtuosity on such instruments as the 21-string harp (kora) and the balaphon (bala), with their propensity to turn beautiful, striking phrases and link metaphor to ideology, and with their abilities to use voiced sound as a complex instrument that rises and falls, and runs with or against the tempo, rhythm, and pitch of a song, these performers generate a heady kind of art that is guaranteed to take deep root in a sizable percentage of the audience. Young people, hearing such performances time and time again, very often get caught up in the spirit of adventure and the will to carry out great deeds.

One of the most popular ways to embrace that spirit of adventure is to become a hunter, and this has long been the case. Sunjata, for example, was a hunter, and Fakoli's family was famous for hunting. Kambili too was a very accomplished hunter, and so it becomes clear that hunting as a vocation is both a means and an end. It helps satisfy the urges that make some men wish to leave the tame spaces of town and society. At the same time it serves as a vehicle, a stepping stone toward becoming a hero. It is no accident that hunters have their own specialized groups of bards (donson jeliw) who perform strictly for hunters and whose repertoires are composed of praise songs and lengthy epics about the great legendary hunters. Interestingly enough, the bards also wear dramatic shirts covered with amulets and references to the bush (Fig. 2).
We believe now that when the Maninka and other Mande groups began expanding to the south, hunters helped lead the way. We also believe that the great armies that helped build the Mande states and empires were formulated from groups of expert hunters. This is not surprising because, after all, hunting is a vocation that puts hardy souls in the most dangerous of environments, the wilderness, and expects them to survive. Properly trained hunters transform this wild space into a very serviceable habitat. They are capable of spending days, weeks, even months in the bush, using its raw materials to satisfy all of their needs. They learn to track and bag wild creatures while protecting themselves from the immense amount of danger that surrounds them. And they learn to use the environment as a pharmacopoeia, to make medicines to heal their ailments and harness supernatural energy.

These two features, learning to hunt while not being hunted and learning to transform organic matter into medical and supernatural materials, are critical to the concept of good traditional Mande hunting. They constitute the essential core of the enterprise. They are also very difficult skills to acquire. The bush after all-the deep bush that is beyond the towns and their farm lands-is a place full of the potential for disaster. Wild and dangerous animals, and reptiles, continue to abound there. So too do the sometimes capricious, sometimes malevolent supernatural creatures called jinew, the wilderness spirits. The smallest of scorpions can be hazardous to health, as can such vegetation as the thorny plants that give off toxic sap. Most Mande citizens are not comfortable in the bush. In fact,

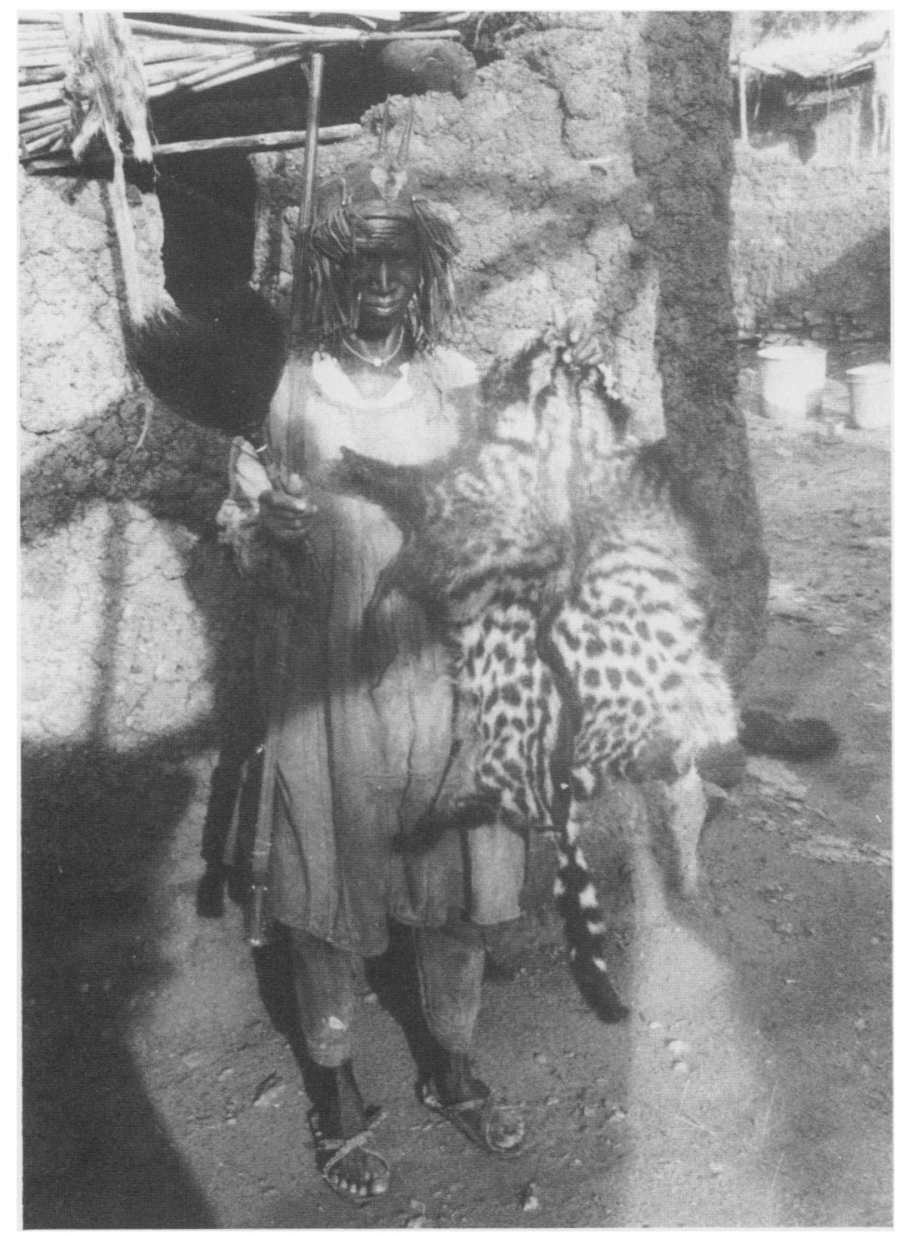

1. SEDU TRAORE, A HUNTER AND BLACKSMITH. WITH A SAMPLE OF HIS HUNTING EXPERTISE 
most avoid it. Neophyte hunters, however, are taught by older members of the profession how to get by in the bush. They learn how to identify danger and how to work around it. Ultimately, for them the bush does not become benign, but it does become manageable. By extension it becomes a natural resource to which few other human beings have recourse.

Learning to use the environment as a pharmacopoeia is as difficult as learning to find game while avoiding danger. It involves what the Mande call the science of the trees, jiridon (McNaughton 1979). ${ }^{2}$ According to this science, most living things have useful parts that can be detached from the whole entity and combined with parts from other living things. Such recombined entities develop properties that can be used to change, to rearticulate one's environment. When made to work on the physical plane they are medicines (furaw) that can cure everything from fevers to bad breath. When made to work on the supernatural plane they are amulets (sebenw) or secret occult devices (basiw) that can perform such diverse tasks as preventing poisonous snake bites or causing a person to fall madly in love.

All of this activity, grounded in the science of the trees, is organized in manageable units called daliluw. A dalilu is essentially a program of action that states a goal and provides a strategy, a recipe if you will, for achieving it (McNaughton 1979, forthcoming; Bird \& Kendall 1980:16-17). Very often herbal chemistry will be involved, and so plants will be identified and their important parts described, along with the proper means for detaching those parts and reducing them to the proper form for use with other ingredients-for example, pounding in a mortar is sometimes called for, as is boiling ingredients in water and combining them in solution. Very often ritual is also involved, and ultimately the products of these units of information can be viewed as a combination of our own brand of Western science and Africa's brand of occult enterprise. Those daliluw that generate products that operate on the supernatural plane are perceived as harnessing the energies that animate our world, the energies referred to by the Mande as Nyama, which give life to all living things and provide the momentum for every act undertaken in the world (McNaughton 1979, forthcoming; Bird \& Kendall 1980:16-17). ${ }^{3}$ That energy is by definition neutral, but it is potentially both helpful and deadly. When properly controlled it can be used to the great benefit of human beings. When out of control, or when under the control of a malevolent individual, it can cause great harm. Hunters, through their science and the daliluw, learn to control enormous quantities of this energy, and that is one of the reasons they are so distinguishable from other citizens. Sorcerers, heroes, hunters, and certain professional artists-like the sculptors and the oral historianscontrol this energy to an extent that greatly surpasses most people, and so they are afforded much respect, and often they are held in awe, even fear.

Thus hunters can be exceptional, formidable individuals with the power to influence society in several ways: as soldiers, sorcerers, and providers of game, as rugged individualists who seek to bend society to their own wills, or as saviors of society when strong characters and the capacity for aggression are in order. All of this registers in their shirts, and we must turn to them shortly.

There is, however, an important distinction between theory and practice that we should address before proceeding. In theory hunters are by definition all of the things we have discussed. In practice, naturally enough, there are good and bad, experienced and inexperienced, serious and frivolous indi- viduals who belong to the profession. Furthermore, while the theory remains the same, especially in the realm of culture symbolism, in practice hunters have become less important in post-colonial West Africa. Fewer seek adventure in the deep bush, and fewer use hunting as a vehicle to become heroes; working or going to school abroad have become alternative strategies for people inclined to become famous. The institution of hunting is still immensely important, but its practice in modern Mali has been toned down somewhat. The same is true of the shirts hunters wear. Few hunters have shirts that are completely covered with the materials that are about to be discussed. Their shirts are built over time, during the course of practicing the activities that constitute the vocation. These days fewer individuals practice them with the abandon, the whole-hearted devotion, that was common before colonialization. Thus one sees fewer elaborate shirts.

\section{The Shirts That Hunters Wear}

When hunters work the bush they dress very practically, in simple pants and shirts that facilitate quiet mobility. Their special shirts are a kind of formal wear that marks them among other citizens (Fig. 3). They are worn for festivals, parades, and other special gatherings in which hunters' associations participate. For example, when a new town market is built, hunters may promenade with their bards as part of the opening ceremonies. A large animal festival is held in San (eastern Mali) to honor the founding of that city in the 1300 s by a legendary hunter named Koyate. The celebration lasts three days, and on the afternoon and night of the second day hunters amass in large numbers to dance and perform such feats as fire spitting. In the capital of Bamako the annual independence day parade always includes branches of the hunters' association, who sometimes perform magical feats like causing water spouts to erupt from the pavement by striking it with their gun butts. Most hunters are quite proud of their identity, and so they often wear their special shirts around town, just because they are hunters.

These shirts contrast sharply with the clothes most people wear. Other peoples' clothes-be they of simple white cotton, multicolored woven patterns, or complex stamp-dyed configurations-are imbued with the precision and clarity of civilization itself. They can be extremely intricate and provocatively designed, but they remain within the bounds of a visual organization universal to the Mande. This organization focuses on structure and essence and seeks a level of abstraction that captures an object's or concept's fundamental core. The Mande call this jayan, "precision and clarity." Charles Bird describes it as a quest for simplicity, generality, and the elegance of science. ${ }^{4}$

Hunters' shirts, at least at first glance, seem anything but concise. Old examples owned by expert hunters give the impression of having emerged full blown from the bush. They almost sting the eyes with large quantities of attachments, with horns and claws, strips of rawhide and skin-covered amulets. Indeed, such shirts seem a conceptual model of the bush, with references to its wild creatures and the means for gaining control over them. The cloth is often stained with a herbal solution that turns white cotton a rusty brown. Sometimes mud-dyed cloth called bogolanfini is used, and then the overlay of attachments is even more dramatic because it obliterates the very complex pattern of off-white and black motifs characteristic of mud cloth (Imperato 1970:34).

Hunters' shirts begin quite simply as strips of woven cotton cloth sewn together with vertical seams, as is typical all over 


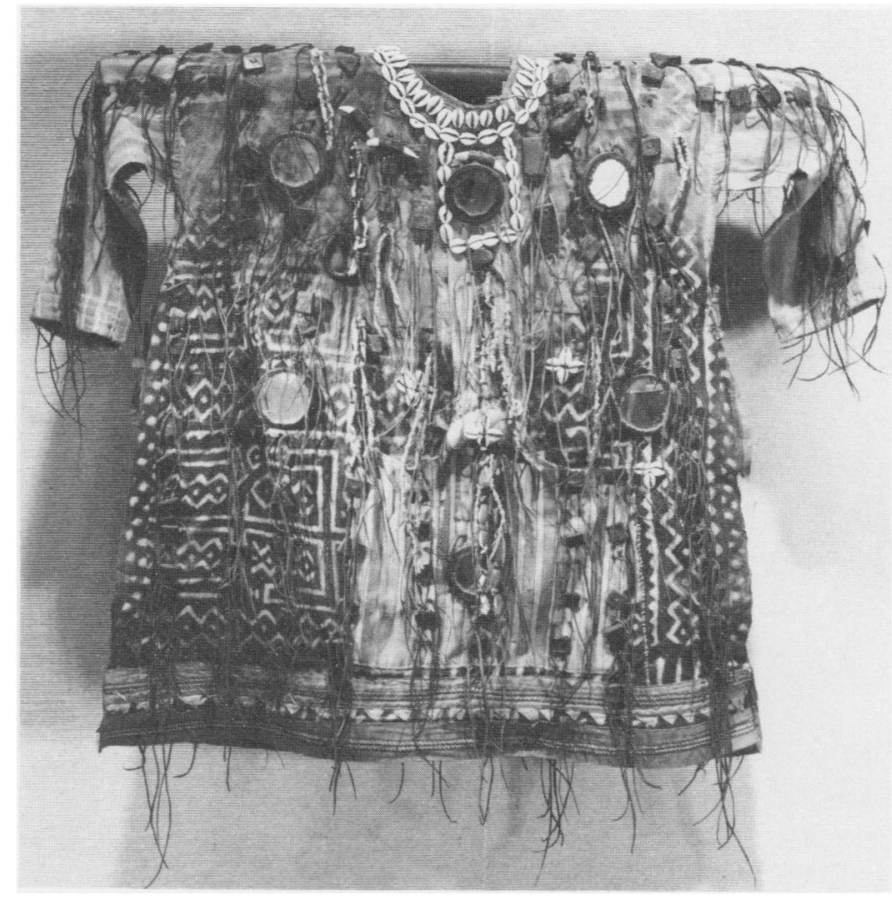

2. SEYDOU CAMERA'S SHIRT. COLLECTION OF CHARLES BIRD \& MARTHA KENDALL

West Africa with cloth made on narrow strip looms. They resemble the shirts Mande farmers customarily wear, but they are sometimes composed of larger quantities of cloth, often dyed in broad, lengthy patterns (Fig. 4). They can measure more than 75 centimeters from shoulder to shoulder and may extend well below the waist. The area under the arms is left open on some shirts. A single cloth strip ending below the armpit will then join the front and back panels. Such shirts don't have sleeves, but a strip of cloth may extend from the upper shoulder, sometimes as far as the owner's elbow. Other shirts have actual sleeves and are completely closed at the sides. Large pockets are generally sewn onto the shirt fronts, beginning just below the chest. The tops may be shaped like triangles for quick, easy access. Hunters prefer large shirts, and, even though they can be quite heavy, their roominess produces a kind of comfort by catching and cooling air.

When a young hunter begins a shirt it will remain for some time in a relatively simple state. He will attach several leathercovered amulets (sebenw) to it at once, some designed to protect him from danger, others designed to enlarge his prowess. Elder hunters, his teachers, may give him amulets as part of his initiation and training, or simply in response to personal characteristics that can be developed or should be negated. At this point a shirt will be "uncluttered" and readily comprehensible. A handful of attachments heralds the status of its owner and serves as a hunters' refrain in a world where clothes are vibrant symbols.

The shirts of many hunters will remain in this state indefinitely. This is especially true today because the institution is less centrally affixed to the fabric of society. Hunters' groups are no longer fundamentally a militia, and fewer hunters spend large amounts of time in the bush. Thus, fewer hunters become masters than in the days before colonialization, and fewer hunters become heroes.

Still, drive and destiny continue to make some men great hunters, and the shirts of these individuals grow continuously. Such men pursue their avocation with a tough-minded dedication that constantly registers in their shirts. They expand themselves along the dual fronts of theory and practice. In the realm of theory, they systematically extend their knowledge ever deeper into the bush's flora and fauna, and into the world of sorcery. To do so they must master vast portions of the "science of the trees." They can learn from other hunters and from persons known as kara-mogow, individuals full of age and wisdom, who enjoy teaching and are held in the highest regard by their communities. Often the kind of knowledge a hunter seeks is not available in his own town or even his own region. A serious hunter may travel 160 kilometers and more to acquire a useful bit of information (a dalilu), and, because in the Mande world knowledge is always paid for, he will be willing to invest a good deal in his own education. Many of these bits of information result in the manufacture of amulets that are sewn to the hunter's shirt. New amulets constantly appear because hunters subscribe to the letter of another Mande axiom regarding education: for persons wishing to fulfill their aspirations, education is a never-ending process.

In the realm of practice, aspiring hunters put their growing knowledge and supernatural prowess to the test in the bush as often as they can. Survival there is what distinguishes "men of the bush" from "men of the house." Success at hunting makes the distinction vivid. ${ }^{5}$ When an animal is killed, one of its most graphic components will be removed and attached to the hunter's shirt. When a Mande sculptor reduces an antelope to its essential elements for a $C i$ wara headdress, he will emphasize horns, mane, and gracefulness. A hunter goes a step further toward abstraction by using only the horns, while traveling a step back toward reality because the horns are real. Once attached to a hunter's shirt, such objects become artifacts of the hunt; they visually articulate the history of the hunter. As a man gains skill and experience, his shirt verifies the fact. It becomes, in effect, an index of the hunter's greatness. Simultaneously, it comes more and more to resemble the bush itself, just as its owner is more and more closely identified with the arena in which he is so successful. The shirts of the very best hunters are littered with the small horns of antelope, the curved fangs of wild boar, and the claws of large herbivores and cats. One cannot look at them without being impressed.

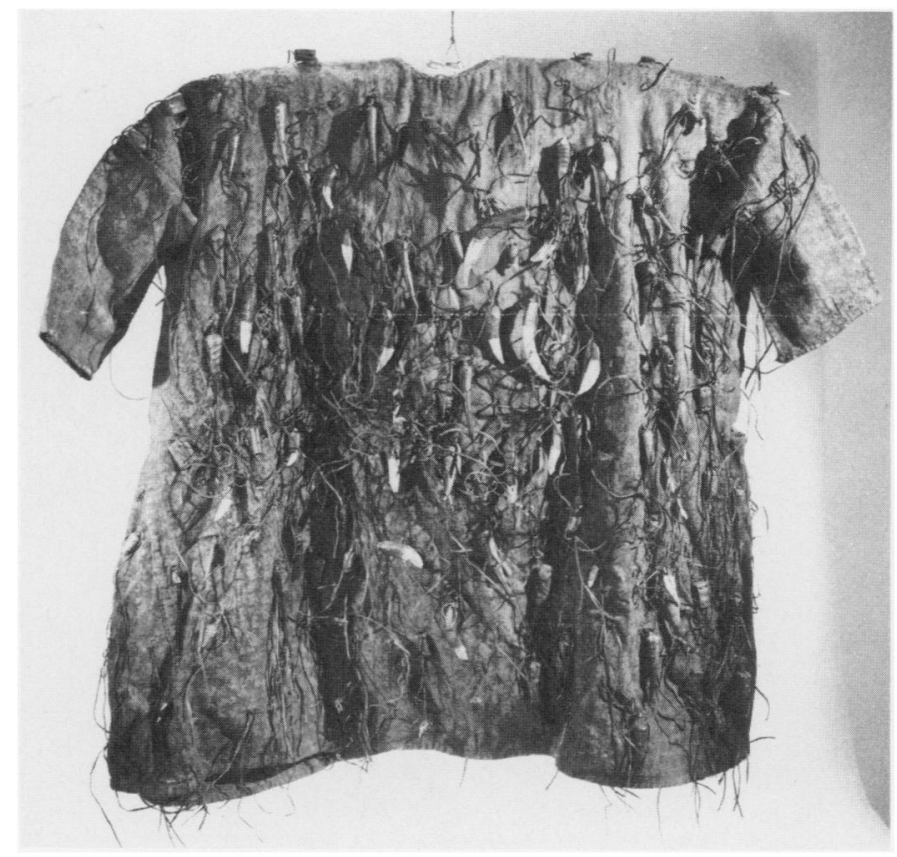

3. COMPLEX MANDE HUNTER'S SHIRT, EXACT PROVENANCE UNKNOWN. PRIVATE COLLECTION 
These additions are not simple proclamations of a man's abilities. Because they are changed before they are attached they become amulets, like the leather-covered packets. Traditionally, horns are used to contain medicines (furaw), and all of these natural elements can be set in a base of carefully sewn hide and filled with secret materials. Thus they become basiw, the "secret things" people own to help them be more powerful. In a sense, when they are assembled on a hunter's shirt they reconstruct the vitality of the bush, although the energies are now of a different valence.

We can focus more directly on the symbolisms and implications of these shirts. First, we have seen that they indicate the prowess and ability of their owners. Iconographically they revolve around the concept of power (Nyama) that grounds Mande thinking on the structure and forces at work in our world. The shirts also refer to power and the bush in another way. As they expand, they gradually obliterate one's sense of the cloth underneath. They grow oblique and murky. Individual components are not readily discerned, especially by people not used to looking into dense and intricate spaces. Ultimately they approach a Mande concept that contrasts sharply with jayan, "clarity and precision." Called dibi, it is at one level likened to darkness and the night. At another level it means obscurity, ambiguity, and potentially devastating power. At yet another level dibi is death. Mande sometimes refer to the kill-

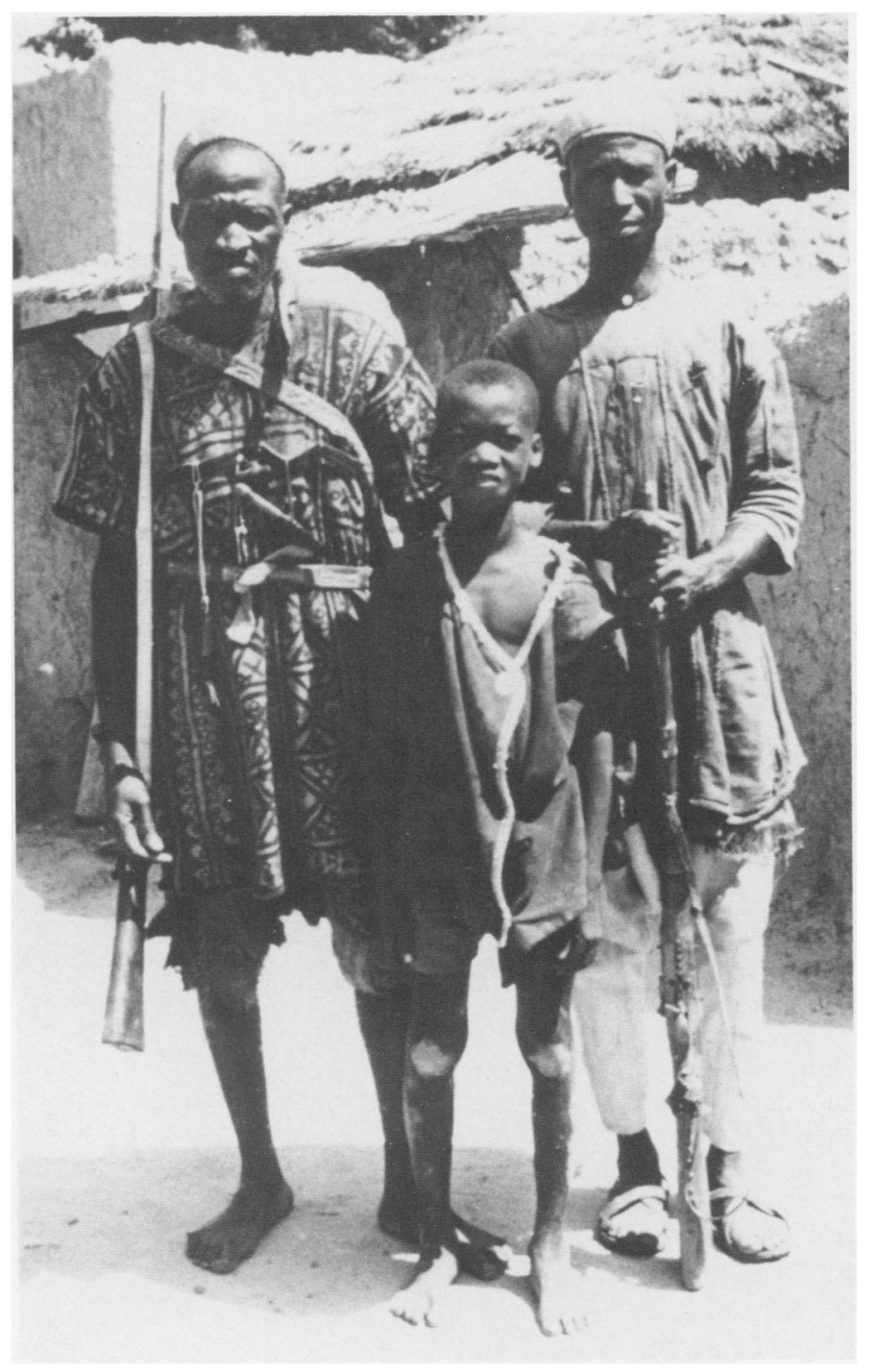

4. SEDU TRAORE WITH A HUNTING FRIEND. ing of something by saying, " $\mathrm{N}$ ' ye a bila dibi ro" ("I put it into darkness"). The bush is a place of dibi, and the world of sorcery is submerged in it. ${ }^{6}$ The shirts that hunters wear suggest that their owners are a part of that world and are comfortable in it. To amplify the fact, they may be strewn with long, thin strips of hide that move across the "composition" like vegetation. Mirrors can also be attached, and they are especially popular on the shirts worn by hunters' bards (Fig. 2). They flash when they catch the light, punctuating the mystery of the shirts and suggesting the vital forces and spirits that must be dealt with by the hunters and their bards.

Horns and other bony materials make obvious reference to the creatures from which they have been detached, and to the power of the bush. They make another reference, too, which they share with the powerful types of Mande sculpture used in the secret initiation associations. Binye is the word for horn, but it can also refer to any sharp projection and any object with the capacity to pierce. Bullets, for example, can be called binye. Iconographically the term partakes of yet another axiom about education: knowledge is a major basis of power. Certain kinds of knowledge produce power that can be used aggressively. Fakoli, the great Maninka ally of Sunjata, is described in oral tradition as possessing an enormous head from which 313 sharp projectiles emerged. He is also described as one of Africa's greatest military strategists. ${ }^{7}$ Thus shirts full of horns and other sharp elements of nature support one of the hunters' praise names, don-sogo, "great buffalo piercer."

The implications of amulets attached to hunters' shirts are reflexive, this according to another tenet of traditional education. A Mande proverb states, "The best way to know yourself is through your daliluw" (Yeredon nyogon te daliluw la). ${ }^{8}$ Two virtues are referred to here. First, for everyone, but especially for those with grand aspirations, self-understanding is of the greatest importance. They must be aware of their character and their destiny, and they must possess the capacity to bend the one to suit the other. Then follows the pursuit of knowledge, the second virtue. Each dalilu is a formula for making something tangible like a "secret thing" (basi) or a leathercovered power packet (seben), and for the marshalling of useful energy. Wise persons constantly seek to increase their store of daliluw by acquiring those that complement their development or stimulate new growth. ${ }^{9}$ In attaching the horns and packets to their shirts, hunters are in effect wearing their daliluw. In so doing they plainly state that they know themselves very well indeed.

Hunters can be very careful about where they attach each new component of their shirts. Some possess a wonderful sense of design. Another kind of beauty pertains to these shirts, however, which draws upon Mande beliefs about power. Nyama is more than the energy that animates our universe. It is also a moral force that helps protect the balance in nature. In general the more delicate and defenseless a creature is, the more Nyama it possesses, and the more dangerous it is to kill it. Duiker antelopes, called sineri, are very small and delicate. They look almost fragile and are considered by the Mande to be extremely beautiful. They contain huge quantities of Nyama, however, and so they are not easy victims. It is considered quite dangerous for hunters to kill them. One must possess much personal power and know the appropriate placating rituals, and still it is no easy task. Yet the horns of these antelopes appear with frequency on the shirts and hats of hunters. They are signs of ultimate prowess, arcane knowledge and, therefore, great distinction. They lend even more power to the clothes they grace, and to hunters they are quite simply beautiful. ${ }^{10}$

Notes, page 91 
(Kate Kent, personal communication, May 1980). Bibliography

Adams, Capt. John. 1966. Remarks on the Country Extending from Cape Palmas to the River Conto. London: Frank Cass \& Co. 1st ed. 1823

Aronson, Lisa. 1980a. "Akwete Weaving and Patronage," African Arts 13, 3 (May): 62-66.

Aronson, Lisa. 1980b. "Cloth Trade in the Niger Delta: A Study of Diffusion," Textile History 11:89-107.

Bosman, Willem. 1967. A New and Accurate Description of the Coast of Guinea. London: Frank Cass \& Co. 1st ed. 1705

Cornevin, Robert. 1969. Histoire du Togo. Paris: Editions Berget-Levrault.

Crow, Hugh. 1970. Memoirs of the Late Captain Hugh Crow of Liverpool. London: Frank Cass \& Co. 1st ed. 1830.

Kea, R. A. 1969. "Akwamu-Anlo Relations, c. 1750-1813," Transactions of the Historical Society of Ghana 10:29-63.

Perani, Judith. 1977. Nupe Crafts: The Dynamics of Change in Nineteen th and Twentieth Century Weaving and Brasswork ing. Bloomington, Indiana.

Sieber, Roy. 1973. African Textiles and Decorative Arts. New York: Museum of Modern Art.

Talbot, P. A. 1967. Tribes of the Niger Delta. New York: Barnes and Noble. 1st ed. 1932

Talbot, P. A. 1969. The Peoples of Southern Nigeria. London: F Cass. 1st ed. 1926

WOLFF, Notes, from page 70

The research for this paper was carried out as part of a study on socioeconomic change in carving production at Adug bologe Compound in Itoko township, Abeokuta, from fall 1972 to spring 1974. Fieldwork was supported by Fulbright-Hays Doctoral Dissertation Grant and done with the cooperation of the Nigerian Department of Antiquities. wish to thank the many Abeokuta and Itoko people who aided me in this research, particularly the carvers of Adug bologe Compound.

1. Peter Lloyd noted that at such social events as a funeral weekend, "a wealthy man or woman may appear in several changes of costume, each costing up to $£ 100$ exclusive of gold ornaments . . ." (Lloyd 1974:118)

2. In some areas, the corpse is wrapped in a special type of black and white funeral cloth for burial (Parrinder 1953:43).

3. See the special issue of African Arts (vol.11, no. 3, 1978) for a series of articles that give evidence of contemporary Egungun society activitie.

4. "Emic labels" refer to folk categories or classification systems that utilize criteria meaningul to the Yoruba them selves, as opposed to "etic labels," which are imposed by scholars on the basis of formal attributes. See Warren \& Andrews (1977) for an example of a detailed analysis of emic criteria in an African art tradition.

5. Articles and monographs dealing with Egungun masquerading include Bascom 1944; Morton-Williams 1954; Thompson 1971, 1974; Olajubu \& Ojo 1977; and Drewal 1978. 6. The 1973 Itoko Egungun festival started on April 9 and lasted seven days.

7. Egungun are taken up under a number of circumstances but only by members of families associated with the Egungun society, currently or in the past.

8. To take up the Egungun ode, or "hunter's masquerader," man need not be a member of a hunting lineage, but it is necessary that he be a worshipper of Ogun, the deity of all who use metal tools in their work.

9.Egungun alate, the "Egungun that carries a tray," is an emic category that, like those based on personality, cuts across other emic types.

10. For a more detailed description of the formal attributes and symbolism of the ere Egungun erin, see N. Wolff's commentary on the headdress of this type in the Tishman collection (Vogel 1981:110-11).

Bibliography

Bascom, William. 1969. Ifa Divination. Bloomington: Indiana University Press.

Bascom, William. 1944. "The Sociological Role of the Yoruba Cult-Group," Memoirs of the American Anthropological Association 63.

Biobaku, Saburi O. 1957. The Egba and Their Neighbours: 1842-1872. Oxford: Clarendon Press.

De Negri, Eve. 1962. "Yoruba Men's Costume," Nigeria $73: 4-12$

Drewal, Henry John, ed. 1978. African Arts 11, 3. Special issue on Yoruba Egungun, with articles by M. Houlberg, M. \& H. Drewal, J. Pemberton, M. Schiltz, J. Adedeji, R. Poynor.)

Johnson, Samuel.1921. The History of the Yorubas, edited by O. Johnson. Lagos: C.M.S. (Nigeria) Bookshops

Lawal, Babatunde. 1977. "The Living Dead: Art and Immortality among the Yoruba of Nigeria," Africa 47:50-61.

Lloyd, Peter C. 1974. Power and Independence. London: Rout ledge \& Kegan Paul

Lucas, J. Olumide. 1948. The Religion of the Yorubas. Lagos: C.M.S. Bookshop.

Morton-Williams, D.P.M. 1954. "The Egungun Society in South Western Yoruba Kingdoms," Proc. 3rd Ann. Conf. W. Afr. Inst. Soc. \& Econ. Research, Ibadan.

Olajubu, Chief Oludare and J.R.O. Ojo. 1977. "Some Aspects of Oyo Yoruba Masquerades," Africa 47:253-75.

Parrinder, Geoffrey. 1953. Religion in an African City. London: Oxford University Press.
Thompson, Robert Farris. 1971. Black Gods and Kings. Los Angeles: University of California Press.

Thompson, Robert Farris. 1974. African Art in Motion. Los Angeles: University of California Press.

Vogel, Susan, ed. 1981. For Spirits and Kings. New York: Metropolitan Museum of Art.

Warren, Dennis M. and J. K. Andrews. 1977. An Ethnoscientific Approach to Akan Arts and Aesthetics. Working Papers in the Traditional Arts 3. Philadelphia: Institute for the Study of Human Issues.

Westcott, Joan. 1962. "The Sculpture and Myths of EshuElegba," Africa 32:336-53.

\section{McNAUGHTON, Notes, from page 58}

My research in the Republic of Mali has not focused on hunters or their clothes. I have worked extensively with sculptor-smiths, and so I have come in frequent contact with the ideas of knowledge, sorcery, and the bush that characterize the nature of hunting and influence the activities of hunters. In addition, many sculptor-smiths are also hunters, including the one (Sedu Traore) with whom I have worked most closely. Thus I suspect my data are reasonably worked most closely. Thus I suspect my data are reasonably dependable. I want to thank Sedu Traore, and Seydou Camara, Sekuba Camara, Kalilou Tera, Chieckna Sangare, Charles Bird, John Johnson, Jim Brink, Mary Jo Arnoldi, suggestions, and encouragement they have all offered up during the past few years. For the funds that allowed me to work in Mali I want to thank the Social Science Research Council and the University of Wisconsin-Milwaukee Council and the University of Wisconsin-Milwaukee
Graduate School. The generosity of both has been very welcome. I thank, too, the government of the Republic of Mali; the Institut de Science Humain in the Ministere de l'Education Nationale was extremely helpful both in 1972 and 1978. I have followed the proper orthography for Bamana words, as set forth in Lexique Bambara, by the Ministère de l'Education Nationale, 1968, except in instances where individual Malian authors or artists have already established their names in publications using other orthographies. However, African Arts is unable to print accents indicating the open $e$ and open o symbols.

1. Given the phenomenal importance of traditional hunters in Mande society precious little has been published on them. The reader may enjoy consulting Travelé 1928:207212; Sidibé 1930:48-67; and, for the work that has become the classic reference on Mande hunters, Youssouf Cissé 1964:175-226.

2. I discuss this "science of trees" at length in The Mande Sculptor-Smiths, forthcoming from Indiana University Press.

3. Many scholars have written on Nyama. Perhaps two of the most interesting sources are Germaine Dieterlen (1951:62-65) and Cissé (1964:192-208). Often this energy or force has been interpreted as consistently malevolent, negative or evil. I argue against this position in my forthcoming Sculptor-Smiths.

4. Charles Bird, personal communication, March 1976

5. Cissé discusses a "Tour Du Monde" undertaken by young hunters in times past (1964:184-86). Such trips were generally of six months' duration but could be as long as eighteen. The hunters went out in groups of two or three, and sometimes they traveled alone. The goal was to acquire a name for oneself by proving one's ability and knowledge, while simultaneously expanding both ability and knowledge. The "trophies" they returned with included, accord- ing to Cissé: "peaux de fauves, défenses d'éléphants ou $\mathrm{d}$ 'hippopotames, cornes de bufles et d'antilopes, queues do toutes les betes abattues qui étaient reunies en un fagot d'autant plus lourd que le chasseur était adroit."

6. Komo masks, for example, are described as dibi-finw"things of dibi," "things of darkness"- that enter the world of obscurity to fight treachery, malevolent sorcery, and all manner of unpleasant activities.

7. Kalilou Tera, personal communication, July 1977.

Medicines, the head, and potent sorcery are also associated in Yoruba thought. See Drewal 1977:43-45, 91

8. Charles Bird, personal communication, December 1976.

9. The blacksmith and hunter Sedu Traore said this to me on more than one occasion.

10. Interviews with Kalilou Tera, June 1978, and Sekuba Camara, July 1978.

Bibliography

Bird, Charles (with Mamadou Koita \& Bourama Soumaouro). 1974. The Songs of Seydou Camara, Vol. I Kambili. Bloomington: African Studies Center, Indiana University.

Bird, Charles and Martha B. Kendall. 1980. "The Mande Hero: Text and Context," in Explorations in African Systems of Thought, eds. Ivan Karp and Charles Bird. Bloomington: Indiana University Press.

Bravmann, René. 1974. Islam and Tribal Art in West Africa. Cambridge, England: Cambridge University Press.

Cissé, Youssouf. 1964. "Notes sur les sociétés de chasseurs Malinké," Journal de la Société des Africanistes 34.

Dieterlen, Germaine. 1951. Essai sur la religion Bambara. Paris: Presses universitaires de France.

Drewal, Margaret Thompson. 1977. "Projections from the Top in Yoruba Art," African Arts 11, 1.

Imperato, Pascal James. 1970. "Bokolanfini: Mud Cloth of the Bamana of Mali," African Arts 3, 4

Jackson, Michael. 1977. The Kuranko, Dimensions of Social Reality in a West African Society. New York: St. Martin's Press.

Johnson, John W. 1978. "Sun-Jata: An Attempt to Define the Model for African Epic Poetry." Ph.D. dissertation Indiana University.

McNaughton, Patrick. R. 1979. Secret Sculptures of Komo: Art and Power in Bamana (Bambara) Initiation Associations. Philadelphia: Institute for the Study of Human Issues.

McNaughton, Patrick R. Forthcoming. The Mande Sculptor-Smiths. Bloomington: Indiana University Press

Quinn, Charlotte. 1972. Mandingo Kingdoms of the Senegambia. Evanston: Nor thwestern University Press.

Sidibé, Mamby. 1930. "Nouvelles notes sur la chasse au Birgo (Cercel de Kita, Soudan française)," "Bulletin du Comité d'Etudes Historiques et Scientifiques de l'Afrique Occidentale Française 13

Travelé, Moussa. 1928. "Note sur les coutumes des chasseurs Bambara et Malinke du Cercel de Bamako (Soudan française)," Revue d'Ethnographie et des Traditions Populaires 9, 33.

ROY, Notes, from page 53

The research on which this paper is based was carried out in Upper Volta in 1976-77 and was funded by the Fulbright-Hays Doctoral Research Abroad Program and the International Doctoral Research Program sponsored by the Social Science Research Council and the American Council of Learned Societies.

\section{CONTRIBUTORS}

LISA ARONSON is Assistant Professor of African art at the University of Wisconsin-Stevens Point. She recently defended her Ph.D. dissertation on Akwete weaving at Indiana University.

ARTHUR P. BOURGEOIS is Professor of Art History at Governors State University. He received his Ph.D. from Indiana University.

DANIEL P. BIEBUYCK is H. Rodney Sharp Professor of Anthropology and the Humanities at the University of Delaware.

JOANNE BUBOLZ EICHER, Professor and Head of Textiles and Clothing at the University of Minnesota, Twin Cities, conducted field research in Buguma in 1980.

CARL LIEDHOLM is Professor of Economics at Michigan State University and Director of the Off-Farm Employment Project. He has written Growth and Development of the Nigerian Economy (Michigan State University Press, 1972)

PATRICK R. MCNAUGHTON is Assistant Professor of non-Western art at the University of Wisconsin-Milwaukee. He carried out research in Mali in 1972 and 1978 and is finishing a book on Mande blacksmiths and their art

CHRISTOPHER D. ROY, who received his Ph.D. in art history from Indiana University in 1979, is Assistant Professor in the School of Art and Art History, The University of lowa.

FRED T. SMITH is Assistant Professor of Art History and Director of Museology at the University of Minnesota, Twin Cities.

NORMA H. WOLFF has been teaching anthropology at lowa State University since 1977 